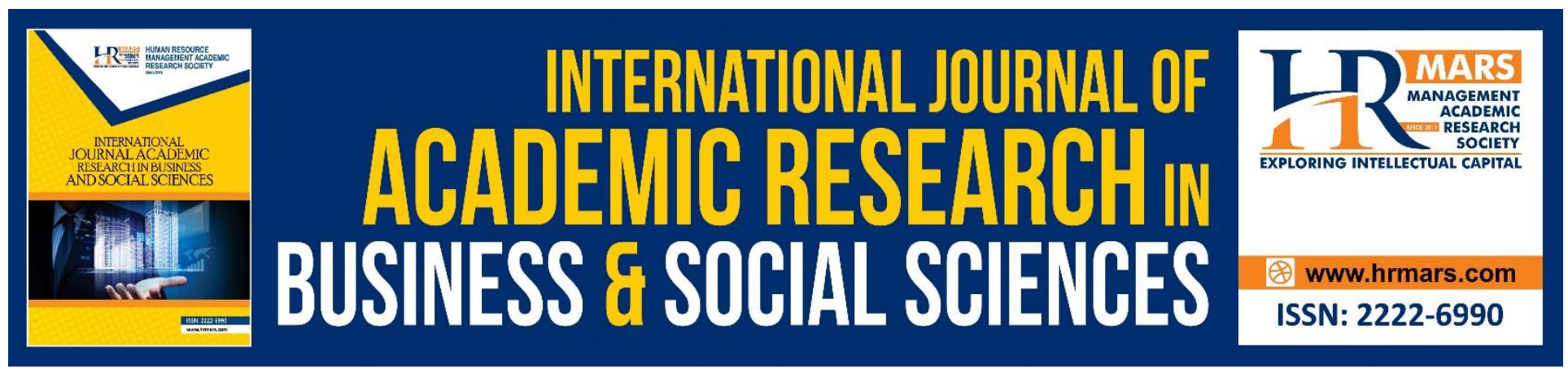

\title{
Talent Development Practices: Does It Really Matters
}

\author{
Bathmavathy Dalayga and Shathees Baskaran
}

To Link this Article: http://dx.doi.org/10.6007/IJARBSS/v9-i6/6050

DOI: 10.6007/IJARBSS/v9-i6/6050

Received: 14 April 2019, Revised: 12 May 2019, Accepted: 03 June 2019

Published Online: 29 June 2019

In-Text Citation: (Dalayga \& Baskaran, 2019)

To Cite this Article: Dalayga, B., \& Baskaran, S. (2019). Talent Development Practices: Does It Really Matters. International Journal of Academic Research in Business and Social Sciences, 9(6), 896-906.

Copyright: (C) 2019 The Author(s)

Published by Human Resource Management Academic Research Society (www.hrmars.com)

This article is published under the Creative Commons Attribution (CC BY 4.0) license. Anyone may reproduce, distribute, translate and create derivative works of this article (for both commercial and non-commercial purposes), subject to full attribution to the original publication and authors. The full terms of this license may be seen at: $\underline{\text { http://creativecommons.org/licences/by/4.0/legalcode }}$

Vol. 9, No. 6, 2019, Pg. $896-906$

http://hrmars.com/index.php/pages/detail/IJARBSS

JOURNAL HOMEPAGE

Full Terms \& Conditions of access and use can be found at http://hrmars.com/index.php/pages/detail/publication-ethics 


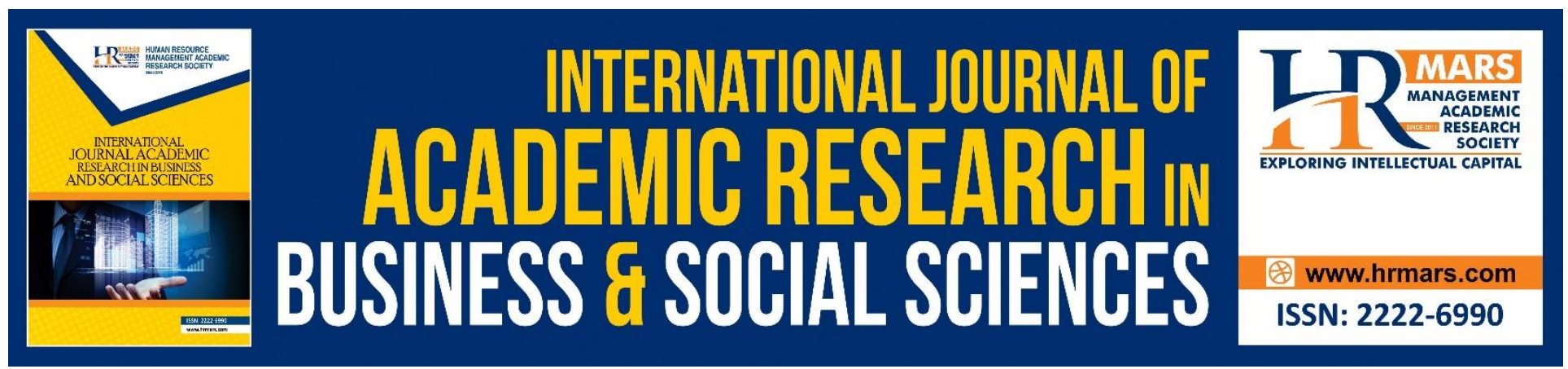

\title{
Talent Development Practices: Does It Really Matters
}

\author{
Bathmavathy Dalayga and Shathees Baskaran \\ International Business School, Level 10, Menara Razak, Universiti Teknologi Malaysia, Jalan Sultan \\ Yahya Petra, 54100 Kuala Lumpur. \\ E-mail: ssbathma@gmail.com and shathees@utm.my
}

\begin{abstract}
Globalization transformed the employment landscape where talent becomes a new differentiator. It appears that managing and retaining talent is the biggest tenacious task that organizations are facing lately. Hence, implementation of talent management strategies, particularly engaging talent development practices has become a lifesaver to retain employees in the organizations. However, talent development getting its least importance since it has been embedded into talent management, lacking a specific focus to this function. The purpose of this study, therefore, is to examine the relationship between talent development practices and intention to stay among employees. A structural equation model was developed and tested on 287 respondents from selected Malaysian private healthcare organizations using self-administered questionnaires. With a response rate of $79.72 \%$, the result indicated a positive significant relationship between talent development practices and intention to stay among employees.
\end{abstract}

Keywords: Talent Development, Training Development, Career Development, Intention to Stay, Human Capital Theory and Malaysian Private Healthcare

\section{Introduction}

The $21^{\text {st }}$ century marks a new era in the employment landscape where the significance of the unequivocal value of talent as a competitive weapon rise (Ott, Tolentino, \& Michailova, 2018; Tlaiss, Martin, \& Hofaidhllaoui, 2017). The bursting term of the new generation employee in the world of academia and real work life gains more attention due to their volatile attitude towards staying with an organization for a longer period (ManpowerGroup, 2018). The swift increase of businesses leads to talent shortages where most of the organizations struggle to fill and retain their employees (Alferaih, Sarwar, \& Eid, 2018). According to the Manpower Group's 2018 Survey, talent shortages for global firms in 2018 peaked at 45\%, an increase of 5\% over 2017 as employers find it increasingly difficult to fill vacancies and retain employees. Moreover, a study by Lee et al., (2018) confirms this issue remains as a major concern for employers globally which seeks more attention to solve it.

Systematically managing and retaining the workforce to sustain business competitiveness is the foremost priority to an organization and talent management as a new mechanism gains its high 
recognition for overcoming talent issues in the market. This is particularly of high significance to the healthcare industry. Healthcare industry becomes very crucial and demanding due to the increasing population of aged citizens who needs medical attention. Hence, retaining talents in this industry which is best characterized as a technical industry is of paramount importance to the healthcare organizations since health is a concern to everyone and provision of quality services has become success formula to many organizations to stay competitive in the market.

Despite recent research suggesting the importance of talent management strategies, talent development receiving less attention due to its nature of being embedded with talent management practices overall (Li, Hedayati-Mehdiabadi, Choi, Wu, \& Bell, 2018; Mehdiabadi \& Li, 2016; Garavan, Carbery, \& Rock, 2012). Besides that, talent management studies and researches are western dominated and are least studied in the Asian context (Gallardo-Gallardo, Nijs, Dries, \& Gallo, 2015).

Increasing number of recent literatures on the issues of talent shortages, talent retention, employee intention to stay and turnover demonstrating how employers struggling to fill their vacancies with much needed talents (Pandita \& Ray, 2018). Therefore, the objective of this study is to examine the effect of talent development practices in improving employee's intention to stay in the selected private healthcare organizations in Malaysia.

\section{Literature Review \\ Talent Development}

Talent development is recognized imperatively as a key component of not only talent management but also in global talent management (Alferaih et al., 2018; Li et al., 2018; Tlaiss et al., 2017). Even though the researches and scholarly articles are very limited in explaining this phenomenon (Mehdiabadi \& Li, 2016), the worth of talent development is clearly seen in the success of the companies in managing talent (Garavan et al., 2012). Talent development mainly focuses on catering "zero talent outages" and to create a solid succession plan rather than talent replacement. Research conducted by Garavan et al., (2012) clearly emphasizes the importance of talent development globally and locally and his studies also suggest that talent development architecture is not a onesize-fits-all approach, but it should be differentiated, with an emphasis on customizing talent development strategies to meet the needs of individuals. An extensive study by Mehdiabadi and Li (2016) signifies that most of the past studies in relation to talent development are cantered around career development, culture and talent, retention of workers, and managing diversified groups of talents. Nevertheless, this research is premised talent development as a standalone variable and not as a part of talent management. For the purpose of this research, training development and career development are considered as two important dimensions in explaining talent development practices.

\section{Training Development}

The employees in the new era endlessly expect and search for newness and ideas to develop their skills and knowledge in developing and enhancing their career path. This makes the art of managing employees more challenging than before. In order to sustain the changing demand of current talents, 
INTERNATIONAL JOURNAL OF ACADEMIC RESEARCH IN BUSINESS AND SOCIAL SCIENCES Vol. 9, No. 6, June, 2019, E-ISSN: 2222-6990 @ 2019 HRMARS

organizations employ different strategies to tackle these dynamics. As such, learning and development of talented employee have become a mainstay for organizational success (Burgard \& Görlitz, 2014) and important for employees towards upgrading their skills to meet the needs of continuously changing environment. Therefore, training development is best alternative apart from raising wages to retain employees in an organization \{Formatting Citation\}.

Training is mainly enthralled on expertise, handiness, and skill fullness capabilities to do a job. It is not to bring into line human capabilities aligned with the strategic plans of an organization. Employees nowadays endlessly expect and search for their growth of skills and ongoing learning to develop and reskilled their competence level. Schmidt (2007, p. 483) cited that according to Patrick (2000), "training is systematic development of the knowledge, skills, and expertise required by a person to effectively perform a given task or job". This systematic development builds the human capital that performs well for the success of their organization. However, not every employer is emphasizing the importance of training development when training cost remains a big obstacle to many organizations. Although the impact of training towards organizational competitiveness has gained vast attention over the years, Memon, Salleh, and Baharom (2016) posited that researches that focus on training and employee outcomes are still lacking. Since trained employees perform better than untrained, the importance of employee training cannot be discounted and needed continued attention.

\section{Career Development}

Career development gained its popularity through various research platforms in developing and creating career growth opportunities for employees to stay in the organization. It may vary rendering to different need of an organizational objective and vision. A promising and enhanced career plan will tie a worker in his/her job. Clear career development plans which include transparent and promising succession plan will always have a positive effect in abating talent shortage (Church, 2014). Employers who give priority to career development mechanism for their employees create a longlasting relationship both ways which benefit the organization (Tsui, et al., 1997).

Career landscape over the years has become more challenging, more complex and open (Hoekstra, 2011). Multiple career roles and development are necessary, and it is timely to address this concern in a volatile business era. According to Hoekstra (2011), there are few roles of career development namely: i. an identity for a talent, ii. continuously crystalize for rigorous commitments for the long term in an organization, iii. significance of a person's career for the environment in creating employee's reputation, iv. idealize the roles of an employee to suit to describe career positions in obtaining their career goals, and, v. construct in recurring variations. It is claimed that a single career path provides limited career growth which will eventually lead to failure of the organization since the employees may explore external opportunities. Therefore, serious consideration should be given to developing career progression to uphold the talents and to improve employee retention. 


\section{Intention to Stay}

Intention to stay can be described as employees' interest to stay and serve in an organization for a longer period, willingly. It is the other side of the coin of intention to leave. A borderless world has created a mobile and agile workforce that demands to work anywhere at any time at any cost (Vaiman, Haslberger, \& Vance, 2015). It has opened more opportunity for talent to move around to choose their career which has increases talent competition. This has created a significant change in the talent market where the best employees placed them strategically to pursue international careers. Therefore, it's been a notable challenge for employers to invent strategies that will tie their employees to their organizations. Realistically, intention to stay brings many benefits to both the employee and employer. Organizations can meet their goals and increase their profits with long staying employees. This is because the longer an employee stays in the organization, the better will be the mastery of knowledge and skills which enhances the competitiveness of the organizations which eventually will result in progressing financial standing.

\section{Human Capital Theory}

The human capital theory emphasizes talents as an exceptional asset to an organization and based on that relevance, it was chosen as an underpinning theory for the current study. Training development and education are two major successors in human capital theory. It underlines that information, experience, and knowledge employee obtain from training development is a form of valuable capital and a great investment that produces returns (Shultz, 1971; Becker, 1962). There are many studies about the talent management field that uses human capital theory apart from the resource-based view theory. Besides that, human capital theory generally supports and stimulates human capitals or talents to operate freely. According to Becker 1992, "all workers are intrinsically identical" as he attempts to prove that "greater knowledge tends to raise the benefits from specialization, and thus tends to raise the optimal division of labor" (p. 318).

\section{Training Development and Intention to Stay}

Training development is acknowledged as a backbone of an organization lately where talents are referred to as an essential asset with a set of knowledge and expertise to win their competitors. Research by Memon, Salleh, and Baharom (2016) highlights that positive relationship among employees led to believe that training development activities are indicators of their value to the organization which in turn make them stay in the organization. Besides this, Memon, Salleh, and Baharom (2016) emphasize that training development activities highlight the importance of people to an organization, thus creating a sense of being valued and increasing the emotional tie between employee and employer. As a result, employees are less likely to leave the organization. This claim further enhanced by Shuck, Twyford, and Reio (2014), who also iterated that training development has a significant negative relationship to turnover intention. Acknowledging that training development has a positive effect on employee intention to stay, the following hypothesis is formulated:

$\mathrm{H} 1$ : There is a significant relationship between training development and intention to stay. 
INTERNATIONAL JOURNAL OF ACADEMIC RESEARCH IN BUSINESS AND SOCIAL SCIENCES

Vol. 9, No. 6, June, 2019, E-ISSN: 2222-6990 @ 2019 HRMARS

\section{Career Development and Intention to Stay}

Career development is a necessary tool to tie and encourage an employee to enrich his skills and commitment to the organization (Schein \& Van Maanen, 2016). According to Muliawan (2009), career development has a strong association with the intention to stay. His study among Information System Auditors in the United States stressed that organizations were recommended to have scheduled career development plans to manage the loss and shortage of skilled employees. It will stimulate employees career satisfaction which in turn retain the talent within the organization. Abraham (2019), indicated that career development significantly affects employee intention to stay with the customizing method according to every single individual. Acknowledging that career development has a significant effect on employee intention to stay, the following hypothesis is formulated:

$\mathrm{H} 2$ : There is a significant relationship between career development and intention to stay.

The following conceptual framework as in Figure 1 portrayed the discussion and hypotheses, that was proposed for the current study.

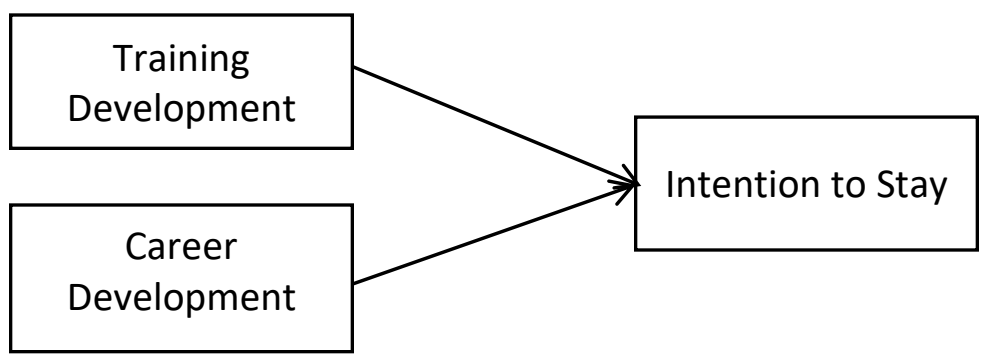

Figure 1: Conceptual Framework

\section{Research Methodology \\ Research Design}

Quantitative method is more pertinently chosen with structured questionnaires to achieve the intended research objectives of this study. According to Cooper and Schindler (2011), quantitative research methods have been well-known far longer than qualitative research methods. The former is mainly to create new-fangled philosophies or hypotheses that will be tested with measurable means. Balnaves and Caputi (2001) observed that quantitative research is not biased and error-free.

\section{Sample and Data Collection}

The targeted population of the present study involved private healthcare organizations that operate in Malaysia, whereas the unit of analysis is the individual employees who are working in that organization for the past one year and above. The large conglomerates such as Kumpulan Perubatan Johor (KPJ), Ramsay Sime Darby and Columbia Asia are typically dominated most of the private healthcare in Malaysia. The private healthcare organizations are selected based on the bed occupancy rate which has 50 beds and above. This is because having more than 50-bed occupancy 
INTERNATIONAL JOURNAL OF ACADEMIC RESEARCH IN BUSINESS AND SOCIAL SCIENCES Vol. 9, No. 6, June, 2019, E-ISSN: 2222-6990 @ 2019 HRMARS

rate and above the premises tend to have higher technology and multiple services to serve the patients with the most advanced, sophisticated and complex medical equipment and tools.

A survey questionnaire designed based on variables from existing literature and used to collect primary data from private healthcare organizations in Malaysia. Neuman (2003) stated that the advantages of self-administered questionnaires are its more conceal and avoid biases. All the respondents were assured that the responses would be confidential and strictly used for academic purposes only. 360 questionnaires were distributed and 287 were returned indicating a response rate of $79.72 \%$.

\section{Measures and Instrumentation}

Well-developed measures used for the questionnaires of this research. The instruments were adopted for this research context. The items for training development measures talents capabilities with the training while for career development how it's boost employee motivation to work harder and learn smart to stay in the organization. Next, the measures for intention to stay were tested on the decision and willingness of employees about their future moves or staying in their organization. In this research, a 7-point Likert scale was used, ranging from 1 indicating strongly disagree to 7, which indicates strongly agree towards the statements given.

\section{Findings and Discussion}

\section{Data Analysis}

In this study, the proposed relationships and the influences of exogenous variables on the dependent variable were analyzed using SEM. SEM is a method with a theory through which the researcher proposes to test the relationship among the chosen variables. $18.8 \%$ of respondents were male while $81.2 \%$ made up female respondents. Majority of the respondents are educated, and the highest education level was Diploma Qualification that sum up to of $52.3 \%$. From a total of 287 respondents, $65.5 \%$ falls into the age group of $26-39$ years old.

\section{Reliability Test}

Reliability assesses the degree of consistency and stability of a variable. Sekaran and Bougie (2010) articulated that reliability of a measure is an indication of the stability as well as the consistency with which the instrument measures the concept and helps to assess the 'goodness of the measure'. The most commonly used test for internal consistency is using the Cronbach- $\alpha$ coefficient (Sekaran \& Bougie, 2010) which can be obtained using SPSS. A higher coefficient value depicts greater internal consistency. Malhotra (2004) ascertained that any $\alpha$ above 0.60 is considered reliable and acceptable. A reliability test was done for this study as shown in Table 1 and the obtained results for the constructs were above 0.60 (i.e. from 0.661 to 0.960 ) concluded that the test instruments met the requirements. 
INTERNATIONAL JOURNAL OF ACADEMIC RESEARCH IN BUSINESS AND SOCIAL SCIENCES

Vol. 9, No. 6, June, 2019, E-ISSN: 2222-6990 @ 2019 HRMARS

Table 1: Reliability Results of Survey Instrument

\begin{tabular}{|l|c|}
\hline Variables under investigation & Cronbach Alpha \\
\hline Training development & 0.949 \\
\hline Career development & 0.960 \\
\hline Intention to stay & 0.661 \\
\hline
\end{tabular}

\section{Results of the Tests of the Hypotheses}

The research tested the direct relationships of training development and career development effects on intention to stay. More specifically, the following hypotheses were tested:

$\mathrm{H} 1$ : There is a positive relationship between training development and intention to stay.

$\mathrm{H} 2$ : There is a positive relationship between career development and intention to stay.

The results of hypotheses testing are shown in Table 2. Based on Table 2, the t-value is 2.392 and 2.030 while the $p$-value is $0.017<0.05$ and $0.043<0.05$ for training development and career development respectively. This result shows a significant relationship between training development and intention to stay and career development and intention to stay. The standardized beta values of 0.213 (for training development) and 0.182 (for career development) also shows that there is sufficient support for a positive association between training development and career development and intention to stay. Therefore, both hypotheses, $\mathrm{H} 1$ and $\mathrm{H} 2$ are accepted.

Table 2 Hypotheses Test Results

\begin{tabular}{|c|c|c|c|c|c|c|c|c|}
\hline H & Relationship & $\boldsymbol{\beta}$ & SD & $\begin{array}{c}\mathbf{T} \\
\text { Value }\end{array}$ & $\begin{array}{c}\mathbf{P} \\
\text { Value }\end{array}$ & $\begin{array}{c}\mathbf{C l} \\
(\mathbf{L L})\end{array}$ & $\begin{array}{c}\mathbf{C l} \\
(\mathbf{U L})\end{array}$ & Support \\
\hline $\mathrm{H} 1$ & TD>ITS & 0.213 & 0.089 & 2.392 & 0.017 & 0.026 & 0.370 & Yes \\
\hline $\mathrm{H} 2$ & $\mathrm{CD}>\mathrm{ITS}$ & 0.182 & 0.089 & 2.030 & 0.043 & 0.018 & 0.366 & Yes \\
\hline
\end{tabular}

\section{Conclusion}

Overall, the findings of the study showed that all hypotheses were supported and had a positive relationship with the intention to stay. Therefore, it was concluded that training development and career development will increase employees' intention to stay in the organization. This evident in past researches which reflected that organizations experience high turnover due to the failure of the company's retention strategy to make their employee stay which has become a continual problem ( Yin-Fah, Foon, Chee-Leong, \& Osma, 2010). Moreover, it is very costly for employers to attract and find new skilled employees with suitable experiences and skills to replace the talents leaving the organizations. As such, the best strategies must be implemented to attract them. These results articulated that talent development has an important function in retaining and boosting employee intention to stay in the organization. 
This study has both theoretical and managerial contributions. This study has contributed to continuous theory by extending the knowledge and filling the gap exist in the study about talent development. The present research has prompted towards more empirical researches in the area of talent management, particularly on talent development practices in private healthcare in Malaysia. Therefore, it is recommended to shift the focus of talent management towards different sectors in Malaysia with more published academic literatures. From the managerial perspective, it has offered insights to the organizations about the benefits of talent development practices in overcoming their talent retention challenges. Additionally, this research has also signaled and the need to either develop a new plan or revitalize their existing talent management programs to make their valuable employees stay in the organization. Besides that, the results confirmed that training development and career development are crucial talent management practices that need greater considerations apart from retention practices. Providing outstanding career development plans and designing tailor fit training development plans are no longer to climb the ladder of promotions, but for gaining more knowledge and mastering the much needed skills to survive the challenges pose by globalization era.

\section{References}

Abraham, I. (2019). Relation between career orientations of employees and their intention to stay : a study of the hotel industry. The Research Journal of Social Sciences, 10(1), 64-73.

Alferaih, A., Sarwar, S., \& Eid, A. (2018). Talent turnover and retention research: The case of tourism sector organisations in Saudi Arabia. Evidence-Based HRM: A Global Forum for Empirical Scholarship, 6(2), 166-186.

Balnaves, M., \& Caputi, P. (2001). Introduction to quantitative research methods. London: SAGE Publications, Ltd.

Becker, G. (1962). Investments in human capital: a theoretical analysis. Journal of Political Economy, Vol. 70, pp. 9-44.

Gary S. Becker (1992). Human Capital: A Theoretical and Empirical Analysis, with Special Reference to Education. $3^{\text {rd }}$ Edition, University of Chicago Press. Chicago and London.

Burgard, C., \& Gorlitz, K. (2014). Continuous training, job satisfaction, and gender: An empirical analysis using German panel data. Evidence-Based HRM: A Global Forum for Empirical Scholarship, 2(2), 126-144.

Church, A. (2014). Succession Planning 2.0: building bench through better execution. Strategic $H R$ Review, 13(6), 233-242.

Cooper, D. \& Schindler, P. (2011) Business Research Methods. 11th Edition, McGraw Hill, Boston.

Gallardo-Gallardo, E., Nijs, S., Dries, N., \& Gallo, P. (2015). Towards an understanding of talent management as a phenomenon-driven field using bibliometric and content analysis. Human Resource Management Review, 25(3), 264-279.

Garavan, T. N., Carbery, R., \& Rock, A. (2012). Mapping talent development: definition, scope and architecture. European Journal of Training and Development, 36(1), 5-24.

Hoekstra, H. A. (2011). A career roles model of career development. Journal of Vocational Behavior, 78(2), 159-173.

Huang, W-R., \& Su, C-H. (2016). The mediating role of job satisfaction in the relationship between job training satisfaction and turnover intentions. Industrial and Commercial Training, 48(1), pp.42- 
INTERNATIONAL JOURNAL OF ACADEMIC RESEARCH IN BUSINESS AND SOCIAL SCIENCES

Vol. 9, No. 6, June, 2019, E-ISSN: 2222-6990 @ 2019 HRMARS

52.

Lee, T. W., Hom, P., Eberly, M. and Li, J. J. (2018) 'Managing employee retention and turnover with 21st century ideas', Organizational Dynamics. Elsevier Inc., 47(2), pp. 88-98.

Li, J., Hedayati-Mehdiabadi, A., Choi, J., Wu, F., \& Bell, A. (2018). Talent management process in Asia: a multiple case study. European Journal of Training and Development, 42(7-8), 499-516.

Malhotra, N. K. (2004). Marketing Research. Prentice Hall, New Jersey.

ManpowerGroup. (2018). 2018 Talent Shortage Survey-Solving the Talent Shortage. ManpowerGroup Survey, 2. Retrieved from https://go.manpowergroup.com/talent-shortage-2018

Mehdiabadi, A. H., \& Li, J. (2016). Understanding Talent Development and Implications for Human Resource Development: An Integrative Literature Review. Human Resource Development Review, 1-32.

Memon, M. A., Rohani Salleh, \& Baharom, M. N. R. (2016). The link between training satisfaction, work engagement and turnover intention. European Journal of Training and Development, 40(6), 407-429.

Muliawan, A. D., Green, P. F., \& Robb, D. A. (2009). The turnover intentions of information systems auditors. International Journal of Accounting Information Systems, 10(3), 117-136.

Nueman, W. L. (2003). Social Research Methods: Qualitative and Quantitative Approaches (5the edition). USA: Pearson Education Inc.

Nazli, N. N. N. N., \& Khairudin, S. M. H. S. (2018). The factors that influence transfer of training and its effect on organizational citizenship behaviour Evidence from Malaysia civil defence force. Journal of Workplace Learning, 30(2), 121-146.

Ott, D. L., Tolentino, J. L., \& Michailova, S. (2018). Effective talent retention approaches. Human Resource Management International Digest, 26(7), 16-19.

Pandita, D., \& Ray, S. (2018). Talent management and employee engagement - a meta-analysis of their impact on talent retention. Industrial and Commercial Training, 50(4), 185-199. https://doi.org/10.1108/ICT-09-2017-0073

Patrick, J. (2000). Training, in Chmiel, N. (Ed.), Introduction to Work and Organizational Psychology, Blackwell, Oxford, pp. 100-125

Sekaran, U., \& Bougie, R. (2010). Research methods for business: A skill-building approach (5th ed.). Haddington: John Wiley \& Sons.

Schein, E. H., \& van Maanen, J. (2016). Career anchors and job/role planning: Tools for career and talent management. Organizational Dynamics, 45(3), 165-173.

Schmidt, S.W. (2007). The relationship between satisfaction with workplace training and overall job satisfaction. Human Resource Development Quarterly, 18(4), pp. 481-498.

Shuck, B., Twyford, D., Reio, T. G., \& Shuck, A. (2014). Human resource development practices and employee engagement: Examining the connection with employee turnover intentions. Human Resource Development Quarterly, 25(2), 239-270.

Schultz, T. W. (1971). Investment in human capital: The role of education and of research. New York: The Free Press

Tlaiss, H. A., Martin, P., \& Hofaidhllaoui, M. (2017). Talent retention: evidence from a multinational firm in France. Employee Relations, 39(4), 426-445.

Tsui, A. S., Pearce, J. L., Porter, L. W., \& Tripoli, A. M. (1997). Alternative Approaches To The Employee- 
Organization Relationship: Does Investment In Employees Pay Off? Academy of Management Journal, 40(5), 1089-1121.

Vaiman, V., Haslberger, A., \& Vance, C. M. (2015). Recognizing the important role of self-initiated expatriates in effective global talent management. Human Resource Management Review, 25(3), 280-286.

Vance, C. M., Chow, I. H., Paik, Y., \& Gale, J. (2015). A Comparative Analysis of Training Method Convergence vs. Divergence in East Asia. International Journal of Learning \& Development, 5(1), 67-85.

Yin-Fah, B. C., Foon, Y. S., Chee-Leong, L., \& Osman, S. (2010). An Exploratory Study on Turnover Intention among Private Sector Employees. International Journal of Business and Management, 5(8). 